\section{Category}

Metal-Catalyzed Asymmetric Synthesis and Stereoselective Reactions

\section{Key words}

\section{palladium}

dehydrogenative olefination

1,3-enynes
Y.-L. SHAO, X.-H. ZHANG,* J.-S. HAN, P. ZHONG* (WENZHOU UNIVERSITY, P. R. OF CHINA) $\mathrm{Pd}(\mathrm{II})$-Catalyzed Dehydrogenative Olefination of Terminal Arylalkynes with Allylic Ethers: General and Selective Access to Linear (Z)-1,3-Enynes

Org. Lett. 2012, 14, 5242-5245.

\title{
Access to 1,3-Enynes by Pd(II)-Catalyzed Dehydrogenative Olefination
}

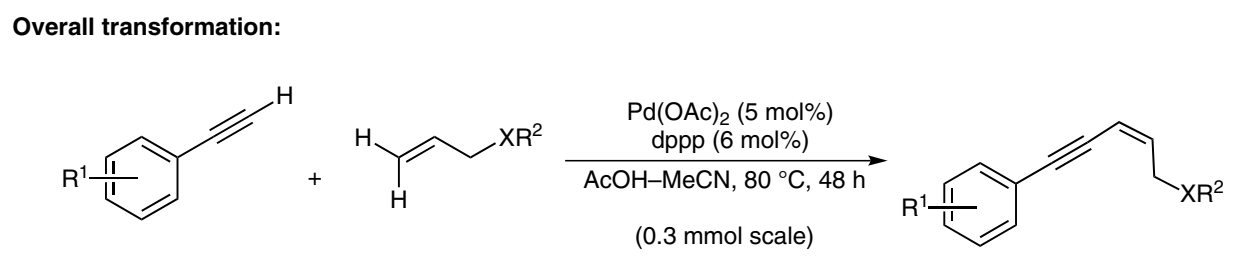

Selected substrate scope:<smiles>COC/C=C\C#Cc1ccccc1</smiles>

$76 \%$ yield<smiles>COC/C=C\C#Cc1ccc(Br)cc1</smiles>

$47 \%$ yield<smiles>CCc1ccc(C#C/C=C\COC)cc1</smiles>

$69 \%$ yield<smiles>CCC/C=C\C#Cc1ccccc1</smiles>

$25 \%$ yield<smiles>COC/C=C\C#Cc1ccc(F)cc1</smiles>

$40 \%$ yield<smiles>C(#Cc1ccccc1)/C=C\COc1ccccc1</smiles>

$85 \%$ yield<smiles>COc1ccc(C#C/C=C\COc2ccccc2)cc1</smiles>

$79 \%$ yield

Significance: 1,3-enynes are important motifs found in pharmaceutically active compounds and natural products. For this reason, efficient methods which easily access these structures are desirable to synthetic chemists. Despite advances made using copper and iron catalysis, which commonly require alkene pre-activation, palladiumcatalyzed dehydrogenative cross-coupling has shown promise as a more benign strategy in this regard.
Comment: The authors report the first example of a $\mathrm{Pd}(\mathrm{OAc})_{2}$-catalyzed direct dehydrogenative olefination of terminal aryl alkynes and allylic ethers to exclusively access (Z)-1,3-enyne derivatives. The reaction exhibits good scope with respect to arylalkynes, however, only allylic ethers and thioethers were used as coupling partners, thus limiting the applicability. Nonetheless, this method appears to be an interesting application of dehydrogenative cross-coupling which accesses these important compounds in a step-efficient manner. 